\title{
Editorial
}

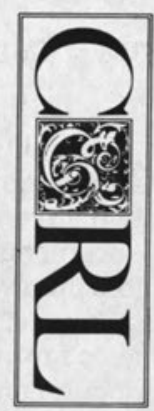

\section{Collegial and Administrative Interface in Faculty Governance}

In May, College \& Research Libraries News published the newly ratified standards for faculty status for librarians. Library governance under this philosophical stance varies from pure faculty models such as that described by Joan Bechtel at Dickinson College to dictatorships with only a shadow of faculty participation. ${ }^{1}$ For most libraries, neither extreme works. What does work is a carefully constructed and nurtured balance between the responsibilities of the faculty for self-governance and the responsibilities of the administrators for meeting university requirements. Pitfalls in achieving a balance between collegial and administrative roles may develop in the areas of personnel, planning and budget, and communications.

Although infrequently acknowledged by librarians, teaching faculty departments are at times run as dictatorships by the chair or oligarchies of the senior tenured professoriate. Clark Kerr's oft repeated maxim that governing faculty is like herding cats troubles library administrators because running a library requires a greater degree of cooperation than does running an academic department. In teaching departments, faculty advise academic administration, while administration, in the guise of department heads or deans, manages the dayto-day, planning, and long-term operations of the departments. In libraries where faculty status exists, the collegial structures advise the dean, university librarian, or director. Because faculty often forget the advisory nature of their input to decision making, a level of organizational dissatisfaction occurs just as it does in other academic departments on campus.

Several examples may be useful. Many personnel decisions involve both collegial input and administrative decision making. When hiring new faculty, a search committee may be charged to seek candidates and to create a short list for administrative consideration. Typically, search committees are not charged to select one candidate, although members often believe that is their duty. In reality these committees may have no role to play in actual selection of the final candidate. Promotion and tenure committees also advise about the suitability of candidates for the particular traits needed for a faculty assignment. But ultimately, selection of the best candidate, at a given salary, is an administrative decision based on consultation with library faculty. The concepts of seeking, screening, and advising often get lost as the committees work through the process.

Similarly, in faculty structures, peer promotion and tenure recommendations are a key part of the academic governance process. Although the library dean or director may not always heed the advice given, faculty input to this process is critical to its integrity. Recommendations by peer committees for nonrenewal of appointments, a collegial mechanism, probably effects the dismissal of more faculty than does administrative decision making. 
Planning and budget are two other areas requiring cooperation between the two governance styles. University faculty documents often require that administrators involve faculty in a planning process. Of course, good management practice argues for full participation, if governance documents do not. Faculty acceptance of a strategic plan is crucial for its successful implementation. For the administrator, a set strategic plan makes it difficult to take advantage of unexpected opportunities. The university librarian who seizes such an opportunity should explain that decision to planning participants. Both the collegial and the administrative structures need to encourage active participation in the creation and continuing revision of strategic plans.

Budgeting ties closely to the planning process. In some states, public university budgets are open documents, and the two processes may proceed openly and in consultation. In other states, budget information is closely guarded and traditionally not shared with faculty or with the public. My informal research indicates that library faculty have only very foggy ideas about the amount of money available for such discretionary items as travel, equipment, and supplies even in those institutions with full disclosure. Although openness about availability of money does not bring happiness, the process within the library should be open and participative. Even in institutions without open information requirements, select faculty budget committees sometimes have an overview and advising function.

Dividing the collections budget is another responsibility typically shared among administration, faculty, and teaching faculty. Often the assistant dean or director responsible for collection management will seek the advice of an internal library committee. Further, a faculty senate appointed committee may want to study the division for equity among the departments and for balance be- tween monographs and serials. While such discussions should create goodwill and a spirit of cooperation, they sometimes devolve into verbal altercations over specific allocations. As painful as these sessions might be, they are a part of an essential interaction between the library and the university.

Open communication and understanding of the unique nature of cooperation are key to a successful coalition between collegial and administrative governance structures. When we as faculty get our own ways, communications have been good. When we do not, communications have failed. Yet, knowing that our concerns are being heard and used in the decision-making process is preferable to thinking that our ideas were not considered. Dividing decision making between collegial and administrative structures requires added efforts at communications. University faculty senates are notoriously sticky about decisions made without their knowledge. Library faculty share that sensitivity. Organizational communication is a rapidly developing field; librarianship needs more research about effective methods for communicating in mixed collegial organizations.

Mark Shields of the "The McNeil/Lehrer News Hour" often comments on how the divided U.S. government, with a president of one party and a congress of another, results in gridlock and stagnation. Competing agendas from a collegial and an administration structure can create library gridlock and organizational dysfunction. Each structure has its own responsibilities and roles. Together they can provide a stronger and more cohesive leadership for a library than either can provide separately. Clear personnel decision making, open planning and budget processes, and effective communications can optimize the Association of College \& Research Libraries' heritage of library faculty status.

GLORIANA ST. CLAIR

\section{REFERENCE}

1. Joan Bechtel, "Collegial Management Breeds Success," American Libraries 12:605-7 (Nov. 1981). 